\title{
ANALISIS INFORMASI CITRA MRI GENU POTONGAN AKSIAL ANTARA SEKUEN SHORT TAU INVERSION RECOVERY (STIR) DAN SEKUEN T2-SPECTRAL ATTENUATION INVERSION RECOVERY (T2-SPAIR)
}

\author{
ANALYSIS OF INFORMATION OF AXIAL GENU MR IMAGING \\ BETWEEN SHORT TAU INVERSION RECOVERY (STIR) SEQUENCE \\ AND T2-SPECTRAL ATTENUATION INVERSION RECOVERY \\ (T2-SPAIR) SEQUENCE
}

\author{
Thuthit Dwi Astuti ${ }^{1)}$, Emi Murniati ${ }^{2)}$, Sri Mulyati ${ }^{3)}$ \\ ${ }^{1)}$ RSUD Kab. Temanggung \\ ${ }^{2,3)}$ Health Polytechnics of Semarang-Indonesia \\ e-mail: thuthit.da@gmail.com
}

\begin{abstract}
Backgrounds: Genu MRI examination, according to Moeller (2003) and Westbrook (2008), was done by one fat supression technique in every slice. Radiology Installation of PAU dr.S.Hardjolukito Yogyakarta Hospital used two types of fat suppression technique those are STIR and T2-SPAIR. This study aims to find out the image differences between STIR and T2-SPAIR and to determine the fat suppresion technique that produces better image information of axial genu MR imaging.

Methods: This research was a quantitative research with an experimental approach. Subjects of this study was image of axial genu MRI examination between STIR and T2- SPAIR in Radiology Installation of PAU dr.S.Hardjolukito Yogyakarta Hospital. The axial genu MR imaging STIR and T2-SPAIR assessed by three radiology phisicians using questioner. Data were statistically analyzed using Wilcoxon Sign Test.

Results: The results showed a significant difference in all categories of assessment criteria between STIR and T2-SPAIR. In this study, the T2-SPAIR fat suppression technique produced better image information than STIR, whereas T2-SPAIR fat suppress signals was stronger than STIR.

Conclusion: T2-SPAIR fat suppress signal was stronger than STIR that showed better image information and shorter time scanning.
\end{abstract}

Keywords: axial genu MR imaging, fat suppresion, short tau inversion recovery, T2-spectral attenuation inversion recovery

\section{PENDAHULUAN}

Magnetic Resonance Imaging (MRI) adalah teknik pencitraan diagnostik medis yang bekerja berdasarkan prinsip resonansi magnetik inti. Pesawat MRI dapat menghasilkan citra diagnostik bagian dalam tubuh manusia baik dalam potongan sagital, koronal, aksial, dan oblik dengan tidak menggunakan radiasi pengion (sinar-X) dan juga tidak menggunakan zat radioaktif. MRI dapat mencitrakan pembuluh darah, kartilago, bone marrow, jaringan otot, jaringan pengikat, dan jaringan-jaringan lunak tubuh manusia lainnya dengan baik (Kartawiguna,2015).

Keunggulan MRI dalam mencitrakan pembuluh darah, kartilago, bone marrow, jaringan otot, jaringan pengikat, dan jaringan-jaringan lunak tubuh manusia lainnya dengan baik, menjadikan pemeriksaan ini sebagai alternatif terbaik dalam rangka menegakkan diagnosa. Salah satunya pada pemeriksaan MRI Genu.

Genu atau knee joint atau lutut merupakan sendi terbesar pada manusia. Sendi ini berperan penting dalam berjalan, berlari dan melompat. Persendian ini terletak di kaki yaitu antara tungkai atas dan tungkai bawah. Pada dasarnya Genu terdiri dari dua articulatio yaitu antara femur dan tibia (tibiofemoral joint) serta antara femur dan patella (patellafemoral joint) yang dikelilingi oleh lemak, tendon, meniskus, dan ligamen. Genu merupakan sendi engsel yang berfungsi fleksi, ekstensi, serta sedikit fungsi endorotasi dan eksorotasi. Dikarenakan banyaknya fungsi sendi pada Genu, maka genu rentan terhadap cedera (Chhajer,2006).

Lemak sering menjadi sumber masalah pada pemeriksaan MRI genu, karena lemak berada di sekitar struktur anatomi sendi genu. Lemak merupakan komponen molekuler dengan atom hidrogen pada cairan. Maka dalam beberapa kondisi, pemeriksaan MRI genu mengalami kesulitan untuk membedakan lemak dan soft tissue. Untuk mengatasi hambatan tersebut diperlukan teknik yang dapat menampilkan citra jaringan tanpa intervensi dari sinyal jaringan lemak disekitarnya. Teknik penekanan lemak ini disebut fat suppression (fat-sup) (Gonçalves, 2011).

Menurut Mc.Robbie (2006) untuk memperlihatkan kelainan patologis genu digunakan salah satu jenis teknik fatsup pada tiap potongan, antara lain Short Tau Inversion Recovery (STIR) atau T2 fat-saturation (fat-sat).

Pemeriksaan MRI Genu mencakup potongan sagital, sagital oblik, koronal dan aksial. Masing-masing potongan mempunyai fungsi yang berbeda, akan tetapi semua potongan saling berkaitan erat dalam menegakkan diagnosa. Potongan aksial sebagai salah satu potongan penyokong diagnosa penyakit pada genu, mempunyai fungsi sebagai tambahan 
informasi potongan lain, serta unggul dalam menampilkan gambaran pembuluh darah dan ruang sendi (Liney,2006).

Informasi dari hasil pencitraan MRI Genu didasarkan pada berbagai macam parameter. Setiap parameter akan memberikan tingkat kontras jaringan yang berbeda-beda. Pemilihan sekuen dan parameter yang tepat akan menghasilkan informasi citra yang optimal dalam rangka penegakan diagnosa. Menurut Moeller (2003) protokol MRI Genu potongan aksial menggunakan sekuen T2W dan Proton Density Weighted (PDW) fat-sat. Menurut Westbrook (2008) protokol MRI Genu potongan aksial menggunakan sekuen T1W, atau T2W atau PDW dan PDW fat-sat atau T2W spectral presaturation.

Dari hasil pengamatan penulis selama PKL di RSPAU dr. S. Hardjolukito Yogyakarta dengan menggunakan modalitas MRI PHILIPS ACHIEVA 1.5 Tesla, pemeriksaan MRI genu khususnya pada potongan aksial menggunakan sekuenPDW sebagai gambaran anatomis, STIR dan T2-SPAIR, yang keduanya merupakan teknik fat-sup, sebagai gambaran patologis. Telah dijelaskan sebelumnya menurut Mc.Robbie (2006), Moeller (2003), dan Westbrook (2008) dibutuhkan hanya satu saja teknik fat-sup pada tiap potongan. Akan tetapi pemeriksaan MRI genu potongan aksial di RSPAU dr. S. Hardjolukito Yogyakarta menggunakan dua teknik fat-sup yaitu STIR dan T2-SPAIR. Dari hasil pengamatan penulis, penggunaan dua teknik fat-sup ini membuat waktu pemeriksaan MRI Genu menjadi lebih lama. Menurut pengamatan penulis di rumah sakit lain, pemeriksaan MRI genu khususnya potongan aksial pada teknik fat-sup, menggunakan hanya satu jenis teknik fat-sup saja. Contohnya di Rumah Sakit Panti Rapih Yogyakarta menggunakan sekuen PD fat-sat, di Rumah Sakit Margono Soekardjo Purwokerto menggunakan sekuen T2 fat-sat.

Short Tau Inversion Recovery (STIR) adalah salah satu teknik fat-suppression yang merupakan bagian dari sekuen inversion recovery, digunakan untuk mengurangi sinyal lemak sehingga untuk kelainan bone marrow dan kelainan organ yang dikelilingi oleh lemak dapat teridentifikasi dengan baik. Sedangkan Spectral Attenuation Inversion Recovery (SPAIR) merupakan teknik fat suppression nhybrid dengan menggunakan adiabatic pulse yang menggabungkan teknik STIR dan fat-sat, tepat dikombinasikan dengan PDW atau T2W. Teknik fat-sup SPAIR hanya terdapat pada beberapa jenis pesawat high Tesla, salah satunya pada pesawat PHILIPS ACHIEVA 1.5 Tesla. Tidak semua pesawat MRI berkekuatan 1.5 Tesla mempunyai teknik fat-sup SPAIR (Philips, 2011).

\section{METODE}

Jenis penelitian ini adalah penelitian kuantitatif dengan pendekatan eksperimental untuk membandingkan perbedaan informasi citra MRI genu potongan aksial antara sekuen STIR dan T2-SPAIR. Lokasi penelitian di Instalasi Radiologi RSPAU dr. S. Hardjolukito Yogyakarta.

Populasi dari penelitian ini adalah seluruh pasien pemeriksaan MRI Genu di Instalasi Radiologi RSPAU dr. S. Hardjolukito Yogyakarta. Sampel berjumlah 10 orang dengan spesifikasi 6 pria dan 4 wanita, dewasa muda berusia 16 sampai dengan 33 tahun dengan berbagai keluhan pada Genu, 3 orang dengan suspect meniscal tears dan 7 orang dengan suspect ruptur ACL.

\begin{tabular}{lccc} 
Tabel 1. Data Pasien \\
Pasien & $\begin{array}{c}\text { Jenis } \\
\text { Kelamin }\end{array}$ & $\begin{array}{c}\text { Usia } \\
\text { (tahun) }\end{array}$ & Klinis \\
\hline Pasien 1 & Pria & 20 & Suspect Meniscal Tears \\
Pasien 2 & Wanita & 25 & Suspect Ruptur ACL \\
Pasien 3 & Pria & 16 & Suspect Ruptur ACL \\
Pasien 4 & Wanita & 26 & Suspect Ruptur ACL \\
Pasien 5 & Pria & 17 & Suspect Ruptur ACL \\
Pasien 6 & Wanita & 19 & Suspect Meniscal Tears \\
Pasien 7 & Pria & 33 & Suspect Meniscal Tears \\
Pasien 8 & Pria & 21 & Suspect Ruptur ACL \\
Pasien 9 & Wanita & 24 & Suspect Ruptur ACL \\
Pasien 10 & Pria & 30 & Suspect Ruptur ACL \\
\hline
\end{tabular}

Responden dalam penelitian ini adalah 3 orang Ahli Radiologi yang kompeten dan expert di bidang MRI untuk membantu menilai citra STIR dan T2-SPAIR secara kualitatif. Responden adalah dokter spesialis radiologi yang sudah berkecimpung aktif memberikan expertise MRI kurang lebih 3 tahun. Masa kerja responden 1 ( 4 tahun), responden 2 (8 tahun) dan responden 3 (4 tahun).

Penelitian ini dilakukan oleh Penulis dengan mengambil data pemeriksaan MRI Genu selama bulan April sampai dengan Juni 2016 di Instalasi Radiologi RSPAU dr. S. Hardjolukito Yogyakarta. Instrumen Penelitian Citra MRI Genu potongan aksial STIR dan T2-SPAIR dalam format DICOM Viewer pada laptop ASUS seri K42F. Kuisioner untuk menilai tampilan lesi patologis pada bone marrow, cortex, articular cartilage, ruang sendi, partial ligamen ACL dan PCL, soft tissue, pembuluh darah dan lesi patologis secara umum pada citra MRI Genu potongan aksial STIR dan T2SPAIR. Pada tahap persiapan dengan melakukan scanning MRI Genu dengan STIR dan T2-SPAIR. Pembuatan citra MRI Genu STIR dan T2- SPAIR dilakukan pada 10 pasien, dengan potongan aksial, posisi supine, feet first dan isocenter di daerah patela. Setiap pasien setelah dilakukan scanning dengan T2-SPAIR, kemudian dilakukan scanning dengan STIR, masing-masing sekuen dibuat sebanyak dua puluh empat irisan. Selanjutnya dari dua puluh empat yang dihasilkan STIR dan T2-SPAIR, dipilih beberapa citra yang dapat menampilkan lesi patologis pada bone marrow, cortex, articular cartilage, ruang sendi, partial ligamen ACL dan PCL, soft tissue, dan pembuluh darah.

Citra MRI disimpan dalam CD untuk 10 orang pasien. Selanjutya citra MRI yang sudah disimpan dalam CD dalam format DICOM. Citra siap dinilai secara kualitatif oleh 3 dokter ahli radiologi. Penilaian Citra Pada tahap ini diawali dengan mempersiapkan kuesioner yang diberikan pada Ahli Radiologi. Citra MRI yang telah tersaji dalam format DICOM untuk dievaluasi oleh Ahli Radiologi. Ahli Radiologi dimohon untuk mencermati citra dari masing-masing pasien satu persatu, khususnya untuk melihat tampilan lesi patologis pada bone marrow, cortex, articular cartilage, ruang sendi, partial ligamen ACL dan PCL, soft tissue, pembuluh darah dan lesi 
patologis secara umum pada citra MRI Genu potongan aksial STIR dan T2-SPAIR. Dalam memberikan penilaian, Ahli Radiologi memberikan tanda check $(\sqrt{ })$ pada kuesioner yang telah disediakan.

Analisa Data penelitian yang dihasilkan melalui penghitungan hasil jawaban kuesioner yang diberikan Ahli Radiologi mengenai tampilan lesi patologis pada bone marrow, cortex, articular cartilage, ruang sendi, partial ligamen ACL dan PCL, soft tissue, pembuluh darah dan lesi patologis secara umum pada citra MRI Genu potongan aksial STIR dan T2-SPAIR.Analisis data dilakukan dengan uji Wilcoxon Sign Test untuk pengujian terhadap hipotesis. Pada analisis statistik ini ditetapkan Ho ditolak apabila p value < 0,05 , yang berarti ada perbedaan informasi citra antara sekuen STIR dan sekuen T2-SPAIR. Untuk mengetahui teknik fat suppresion yang menghasilkan informasi citra yang lebih baik dengan menggunakan meanrank uji Wilcoxon Sign Test dan persentase pada setiap kriteria penilaian lalu diambil kesimpulan.

\section{HASIL}

Penelitian dilakukan pada 10 pasien dengan spesifikasi 6 pria dan 4 wanita dengan usia rata-rata 24 tahun (usia berkisar antara 16 - 33 tahun) dengan berbagai keluhan pada genu, 3 orang dengan suspect meniscal tears dan 7 orang dengan suspect ruptur ACL. Semua pasien dilakukan scaning MRI dengan membuat irisan aksial dengan menggunakan teknik fat-sup sekuen STIR dan T2-SPAIR. Selanjutnya citra dari kedua sekuen tersebut dianalisis secara kualitatif oleh 3 orang Ahli Radiologi yang kompeten dan expert di bidang MRI dengan cara chek $(\sqrt{ })$ pada lembar kuisoner dan selanjutnya diolah dengan menggunakan uji statistik Wilcoxon SignTest. Data kualitatif didapat dari data kuisioner yang dirangkum dan dianalisis berupa data ordinal. Selanjutnya dilakukan penghitungan tabulasi silang (crosstabulation) untuk mengetahui persentase informasi citra yang paling baik di antara kedua sekuen tersebut. Analisis data menggunakan software statistik SPSS versi 16.

Hasil Penilaian Gambaran pada Setiap Kriteria MRI Genu Potongan Aksial teknik fat-sup.Perhitungan data informasi citra diperoleh dengan cara memberikan skor 3 untuk gambaran baik, skor 2 untuk gambaran cukup, dan skor 1 untuk gambaran kurang baik pada setiap informasi citra yang dihasilkan teknik fat-sup sekuen STIR dan T2-SPAIR. Kemudian nilai skor masing-masing informasi citra dari tiga responden tersebut dirangkum dan dianalisis dengan menggunakan uji Wilcoxon Sign Test karena data tersebut adalah 2 kelompok yang perpasangan serta dilakukan pengujian tabulasi silang (crosstabulation) untuk mengetahui persentase informasi citra yang paling baik diantara kedua sekuen tersebut. Berdasarkan penilaian pada setiap krieria terhadap masing-masing citra yang dihasilkan dari sekuen STIR dan T2-SPAIR dengan menggunakan uji beda Wilcoxon Sign Test, pada hasil uji menunjukkan ada perbedaan yang bermakna pada semua kategori kriteria penilaian. Di bawah ini adalah tabel penilaian Uji Wilcoxon Sign Test pada setiap kriteria penilaian pada sekuen STIR dan T2-SPAIR

\section{Rangkuman analisis uji wicoxon sign test :}

Berdasarkan analisis uji Wilcoxon Sign Test tampak ada perbedaan yang bermakna antara gambaran bone marrow pada citra sekuen STIR dan T2-SPAIR dengan $p$ value $<0.001$ (tabel 2). Berdasarkan hasil tabulasi silang hasil penilaian ketiga responden terhadap 10 sampel STIR dan 10 sampelT2SPAIR pada bone marrow yang dapat dilihat pada tabel berikut 2 .

Data pada tabel 3 menunjukkan bahwa dari penilaian ketiga responden terhadap 10 sampel STIR dan 10 sampel T2SPAIR pada bone marrow diperoleh persentase penilaian informasi citra yaitu untuk sekuen STIR, jawaban responden baik (0\%), cukup (50\%), dan kurang baik (0\%). Sedangkan untuk sekuen T2-SPAIR, jawaban responden baik (28\%), cukup (22\%), dan kurang baik (0\%). Jadi $28 \%$ responden menilai sekuen T2-SPAIR lebih baik dari pada STIR untuk gambaran lesi patologis pada bone marrow.

Tabel 2. Hasil Uji Wilcoxon Sign Test penilaian setiap kriteria penilaian pada sekuen STIR dan T2-SPAIR

\begin{tabular}{lccc}
\hline \multicolumn{2}{c}{ Kriteria Penilaian } & Mean & Makna \\
\hline Bone & STIR & 2.00 & Pvalue $<$ \\
Marrow & T-2 SPAIR & 2.57 & 0.001 \\
& STIR & 2.53 & Pvalue $<$ \\
Cortex & T-2 SPAIR & 2.00 & 0.001 \\
Articular & STIR & 1.00 & Pvalue $<$ \\
Cartilage & T-2 SPAIR & 1.67 & 0.001 \\
& STIR & 1.90 & Pvalue $<$ \\
Ruang Sendi & T-2 SPAIR & 3.00 & 0.001 \\
Partial ACL & STIR & 1.00 & Pvalue $<$ \\
dan PCL & T-2 SPAIR & 2.13 & 0.001 \\
Soft Tissue & STIR & 1.00 & Pvalue : \\
& T-2 SPAIR & 1.30 & 0.003 \\
Pembuluh & STIR & 1.00 & Pvalue $<$ \\
Darah & T-2 SPAIR & 3.00 & 0.001 \\
& STIR & 1.00 & Pvalue $<$ \\
Lesi & T-2 SPAIR & 3.00 & 0.001 \\
\hline
\end{tabular}

Gambaran cortex Berdasarkan analisis uji Wilcoxon Sign Test tampak ada perbedaan yang bermakna antara gambaran cortex pada citra sekuen STIR dan T2-SPAIR dengan $p$ value < 0.001 (tabel 2). Berdasarkan hasil tabulasi silang hasil penilaian ketiga responden terhadap 10 sampel STIR dan 10 sampelT2-SPAIR pada cortex yang dapat dilihat pada tabel berikut ini

Tabel 3.Persentase penilaian responden terhadap 10 sampel STIR dan10 sampel T2-SPAIR pada bone marrow

\begin{tabular}{cccc}
\hline Bone marrow & STIR & T2-SPAIR & Jumlah \\
\hline Kurang baik & $0 \%$ & $0 \%$ & $0 \%$ \\
Cukup & $50 \%$ & $22 \%$ & $72 \%$ \\
Baik & $0 \%$ & $28 \%$ & $28 \%$ \\
\hline Total & $50 \%$ & $50 \%$ & $100 \%$ \\
\hline
\end{tabular}


Tabel 4. Persentase penilaian responden terhadap 10 sampel STIR dan10 sampel T2-SPAIR pada cortex

\begin{tabular}{cccc}
\hline Cortex & STIR & T2-SPAIR & Jumlah \\
\hline Kurang baik & $0 \%$ & $0 \%$ & $0 \%$ \\
Cukup & $25 \%$ & $50 \%$ & $75 \%$ \\
Baik & $25 \%$ & $0 \%$ & $25 \%$ \\
\hline Total & $50 \%$ & $50 \%$ & $100 \%$ \\
\hline
\end{tabular}

Data tersebut menunjukkan bahwa dari penilaian ketiga responden terhadap 10 sampel STIR dan 10 sampelT2-SPAIR pada cortex diperoleh persentase penilaian informasi citra yaitu untuk sekuen STIR, jawaban responden baik (25\%), cukup (25\%), dan kurang baik (0\%). Sedangkan untuk sekuen T2-SPAIR, jawaban responden baik (0\%), cukup ( $50 \%$ ), dan kurang baik ( $0 \%$ ). Jadi $25 \%$ responden menilai sekuen STIR lebih baik dari pada T2-SPAIR untuk gambaran cortex.

Gambaran articular cartilage berdasarkan analisis menggunakan SPSS 16 dengan uji Wilcoxon Sign Test tampak ada perbedaan yang bermakna antara gambaran articular cartilage pada citra sekuen STIR dan T2-SPAIR $p$ value < 0.001 (tabel 2). Berdasarkan hasil tabulasi silang hasil penilaian ketiga responden terhadap 10 sampel STIR dan 10 sampelT2-SPAIR pada articular cartilage yang dapat dilihat pada tabel berikut ini.

Tabel 5.Persentase penilaian responden terhadap 10 sampel STIR dan 10 sampel T2-SPAIR pada articular cartilage

\begin{tabular}{cccc}
\hline Articular cartilage & STIR & T2-SPAIR & Jumlah \\
\hline Kurang baik & $50 \%$ & $17 \%$ & $67 \%$ \\
Cukup & $0 \%$ & $33 \%$ & $33 \%$ \\
Baik & $0 \%$ & $0 \%$ & $0 \%$ \\
\hline Total & $50 \%$ & $50 \%$ & $100 \%$ \\
\hline
\end{tabular}

Data pada tabel 5 menunjukkan bahwa dari penilaian ketiga responden terhadap 10 sampel STIR dan 10 sampel T2SPAIR pada articular cartilage diperoleh persentase penilaian informasi citra yaitu untuk sekuen STIR, jawaban responden baik (0\%), cukup (0\%), dan kurang baik (50\%). Sedangkan untuk sekuen T2-SPAIR, jawaban responden baik (0\%), cukup (33\%), dan kurang baik (17\%). Jadi $33 \%$ responden menilai sekuen T2-SPAIR cukup baik dari pada STIR untuk gambaran kelainan patologis pada articular cartilage.

Gambaran ruang sendi berdasarkan analisis menggunakan SPSS 16 dengan uji Wilcoxon Sign Test tampak ada perbedaan yang bermakna antara gambaran ruang sendi pada citra sekuen STIR dan T2-SPAIR dengan $p$ value < 0.001 (tabel 2). Berdasarkan hasil tabulasi silang hasil penilaian ketiga responden terhadap 10 sampel STIR dan 10 sampel T2-SPAIR pada ruang sendi yang dapat dilihat pada tabel berikut ini.

Data pada tabel 6 menunjukkan bahwa dari penilaian ketiga responden terhadap 10 sampel STIR dan 10 sampel T2SPAIR pada ruang sendi diperoleh persentase penilaian informasi citra yaitu untuk sekuen STIR, jawaban responden baik (0 \%), cukup (45\%), dan kurang baik (5\%). Sedangkan untuk sekuen T2-SPAIR, jawaban responden baik (50\%), cukup (0\%), dan kurang baik (0\%). Jadi $50 \%$ responden menilai sekuen T2-SPAIR lebih baik dari pada STIR untuk gambaran kelainan patologis pada ruang sendi

Tabel 6. Persentase penilaian responden terhadap 10 sampel STIR dan 10 sampel T2-SPAIR pada ruang sendi

\begin{tabular}{cccc}
\hline Ruang sendi & STIR & T2-SPAIR & Jumlah \\
\hline Kurang baik & $5 \%$ & $0 \%$ & $5 \%$ \\
Cukup & $45 \%$ & $0 \%$ & $45 \%$ \\
Baik & $0 \%$ & $50 \%$ & $50 \%$ \\
\hline Total & $50 \%$ & $50 \%$ & $100 \%$ \\
\hline
\end{tabular}

Gambaran partial ACL dan PCLBerdasarkan analisis uji Wilcoxon Sign Test tampak ada perbedaan yang bermakna antara gambaran partial ACL dan PCLpada citra sekuen STIR dan T2-SPAIR $p$ value $<0.001$ (tabel 2). Berdasarkan hasil tabulasi silang hasil penilaian ketiga responden terhadap 10 sampel STIR dan 10 sampelT2-SPAIR pada partial ACL dan PCLyang dapat dilihat pada tabel berikut ini.

Tabel 7. Persentase penilaian responden terhadap 10 sampel STIR dan 10 sampel T2-SPAIR pada partial ACL dan PCL

\begin{tabular}{cccc}
\hline $\begin{array}{c}\text { Partial ACL dan } \\
\text { PCL }\end{array}$ & STIR & T2-SPAIR & Jumlah \\
\hline Kurang baik & $50 \%$ & $0 \%$ & $50 \%$ \\
Cukup & $0 \%$ & $7 \%$ & $7 \%$ \\
Baik & $0 \%$ & $43 \%$ & $43 \%$ \\
\hline Total & $50 \%$ & $50 \%$ & $100 \%$ \\
\hline
\end{tabular}

Data berdasarkan tabel 7 menunjukkan bahwa dari penilaian ketiga responden terhadap 10 sampel STIR dan 10 sampel T2-SPAIR pada partial ACL dan PCL diperoleh persentase penilaian informasi citra yaitu untuk sekuen STIR, jawaban responden baik ( $0 \%)$, cukup ( $0 \%)$, dan kurang baik (50 \%). Sedangkan untuk sekuenT2-SPAIR, jawaban responden baik (43\%), cukup (7\%), dan kurang baik (0\%). Jadi $43 \%$ responden menilai sekuen T2-SPAIR lebih baik dari pada STIR untuk gambaran kelainan patologis pada partial ACL dan PCL.

Gambaran soft tissue berdasarkan analisis uji Wilcoxon Sign Test tampak ada perbedaan yang bermakna antara gambaran soft tissue pada citra sekuen STIR dan T2-SPAIR dengan $p$ value $=0.003$ (tabel 2). Berdasarkan hasil tabulasi silang hasil penilaian ketiga responden terhadap 10 sampel STIR dan 10 sampelT2-SPAIR pada soft tissue yang dapat dilihat pada tabel berikut ini.

Tabel 8. Persentase penilaian responden terhadap 10 sampel STIR dan 10 sampel T2-SPAIR citra soft tissue

\begin{tabular}{cccc}
\hline Soft tissue & STIR & T2-SPAIR & Jumlah \\
\hline Kurang baik & $50 \%$ & $0 \%$ & $50 \%$ \\
Cukup & $0 \%$ & $15 \%$ & $15 \%$ \\
Baik & $0 \%$ & $35 \%$ & $35 \%$ \\
\hline Total & $50 \%$ & $50 \%$ & $100 \%$ \\
\hline
\end{tabular}

Data berdasarkan tabel 8 menunjukkan bahwa dari penilaian ketiga responden terhadap 10 sampel STIR dan 10 sampel T2-SPAIR pada soft tissue diperoleh persentase 
penilaian informasi citra yaitu untuk sekuen STIR, jawaban responden baik (0\%), cukup (0\%), dan kurang baik (50\%). Sedangkan untuk sekuenT2-SPAIR, jawaban responden baik (35\%), cukup (15\%), dan kurang baik (0\%). Jadi $35 \%$ responden menilai sekuen T2-SPAIR lebih baik dari pada STIR untuk gambaran kelainan patologis pada soft tissue.

Gambaran pembuluh darah berdasarkan analisis uji Wilcoxon Sign Test tampak ada perbedaan yang bermakna antara gambaran pembuluh darah pada citra sekuen STIR dan T2-SPAIR dengan $p$ value $<0.001$ (Tabel 2). Berdasarkan hasil tabulasi silang hasil penilaian ketiga responden terhadap 10 sampel STIR dan 10 sampel T2-SPAIR pada pembuluh darah yang dapat dilihat pada tabel berikut ini.

Tabel 9. Persentase penilaian responden terhadap 10 sampel STIR dan 10 sampel T2-SPAIR pada pembuluh darah

\begin{tabular}{cccc}
\hline Pembuluh darah & STIR & T2-SPAIR & Jumlah \\
\hline Kurang baik & $50 \%$ & $0 \%$ & $50 \%$ \\
Cukup & $0 \%$ & $0 \%$ & $0 \%$ \\
Baik & $0 \%$ & $50 \%$ & $50 \%$ \\
\hline Total & $50 \%$ & $50 \%$ & $100 \%$ \\
\hline
\end{tabular}

Data berdasarkan tabel 9 menunjukkan bahwa dari penilaian ketiga responden terhadap 10 sampel STIR dan 10 sampelT2-SPAIR pada pembuluh darah diperoleh persentase penilaian informasi citra yaitu untuk sekuen STIR, jawaban responden baik (0\%), cukup (0\%), dan kurang baik $(50 \%)$. Sedangkan untuk sekuen T2-SPAIR, jawaban responden baik (50\%), cukup (0\%), dan kurang baik (0\%). Jadi $50 \%$ responden menilai sekuen T2-SPAIR lebih baik dari pada STIR untuk gambaran kelainan patologis pada pembuluh darah.

Gambaran lesi patologis berdasarkan analisis uji Wilcoxon Sign Test tampak ada perbedaan yang bermakna antara gambaran lesi patologis pada citra sekuen STIR dan T2-SPAIR dengan $p$ value $<0.001$ (Tabel 2). Berdasarkan hasil tabulasi silang hasil penilaian ketiga responden terhadap 10 sampel STIR dan 10 sampelT2-SPAIR pada lesi patologisyang dapat dilihat pada tabel berikut ini

Tabel 10. Persentase penilaian responden terhadap 10 sampel STIR dan 10 sampel T2-SPAIR pada lesi patologis

\begin{tabular}{cccc}
\hline Lesi patologis & STIR & T2-SPAIR & Jumlah \\
\hline Kurang baik & $50 \%$ & $0 \%$ & $50 \%$ \\
Cukup & $0 \%$ & $0 \%$ & $0 \%$ \\
Baik & $0 \%$ & $50 \%$ & $50 \%$ \\
\hline Total & $50 \%$ & $50 \%$ & $100 \%$ \\
\hline
\end{tabular}

Data berdasarkan tabel 10 menunjukkan bahwa dari penilaian ketiga responden terhadap 10 sampel STIR dan 10 sampel T2-SPAIR pada lesi patologis diperoleh persentase penilaian informasi citra yaitu untuk sekuen STIR, jawaban responden baik (0\%), cukup (0\%), dan kurang baik (50\%). Sedangkan untuk sekuen T2-SPAIR, jawaban responden baik $(50 \%)$, cukup $(0 \%)$, dan kurang baik $(0 \%)$. Jadi $50 \%$ responden menilai sekuen T2-SPAIR lebih baik dari pada STIR untuk gambaran lesi patologis secara umum.
Hasil Penilaian Gambaran Informasi Citra Secara umum berdasarkan penilaian secara umum yaitu dengan membedakan nilai total koresponden antara teknik fat-sup sekuen STIR dan T2-SPAIR, uji beda Wilcoxon Sign Test menunjukkan adanya perbedaan informasi citra yang bermakna antara teknik fat-sup sekuen STIR dan T2-SPAIR dengan nilai $p$ value $<0.001$. Ini menunjukan bahwa Ho ditolak dan Ha diterima. Serta diperoleh hasil bahwa T2 SPAIR mendapatkan mean Rank 15.5 dan mean 2.73 lebih tinggi dibandingkan dengan STIR mendapatkan mean Rank 0.00 dan mean 1.00. Hal itu menunjukkan bahwa T2-SPAIR adalah teknik fat-sup yang lebih baik daripada STIR pada penelitian ini. Dibawah ini adalah tabel penilaian uji beda secara umum antara teknik fat-sup sekuen STIR dan T2SPAIR.

Tabel 11. Hasil penilaian responden terhadap 10 sampel STIR dan 10 sampel T2-SPAIR pada penilaian uji beda secara umum

\begin{tabular}{cccc}
\hline $\begin{array}{c}\text { Informasi } \\
\text { citra }\end{array}$ & Mean & $\begin{array}{c}\text { Mean } \\
\text { Rank }\end{array}$ & $\begin{array}{c}\text { Tingkat } \\
\text { Kemaknaan }\end{array}$ \\
\hline $\begin{array}{c}\text { Sekuen } \\
\text { STIR }\end{array}$ & 1.00 & 0.00 & \\
\hline $\begin{array}{c}\text { Sekuen T2- } \\
\text { SPAIR }\end{array}$ & 2.73 & 15.5 & 0.001 \\
\hline
\end{tabular}

\section{DISKUSI}

Perbedaan Informasi Citra MRI Genu Potongan Aksial antara Sekuen STIR dan Sekuen T2-SPAIR berdasarkan uji beda Wilcoxon Sign Test menunjukkan adanya perbedaan informasi citra yang bermakna antara teknik fat-sup sekuen STIR dan T2-SPAIR. Ini berarti Ho ditolak dan Ha diterima. Perbedaaninformasi citra antara teknik fat-sup sekuen STIR dan T2-SPAIR dapat dinilai dari tampilan lesi patologis pada bone marrow, cortex, articular cartilage, ruang sendi, partial ligamen ACL dan PCL, soft tissue, pembuluh darah dan lesi patologis secara umum.

Pada bone marrow diperoleh hasil dari tabulasi silang bahwa $28 \%$ responden berpendapat sinyal lesi patologis pada bone marrow pada T2-SPAIR terlihat hyperintens dibandingkan pada STIR.

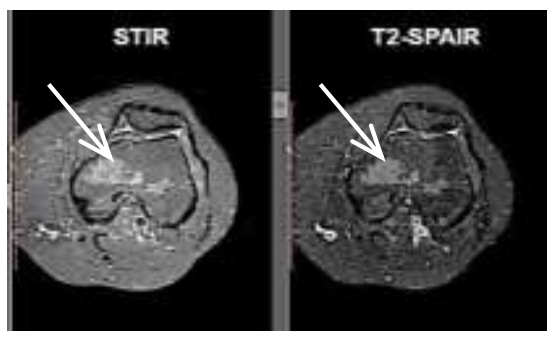

Gambar 1. Perbedaan citra pemeriksaan MRI Genu potongan aksial antara STIR dan T2-SPAIR untuk gambaran bone marrow (tanda panah).

Pada cortex diperoleh hasil dari tabulasi silang bahwa $25 \%$ responden berpendapat gambaran cortex (batas lapisan luar dari tulang) pada STIR terlihat lebih tegas dibandingkan pada T2-SPAIR. Ketebalan dan kontur cortex terlihat lebih tegas pada gambaran STIR (gambar 3 tanda panah) 
dibandingkan dengan T2-SPAIR. Hal ini disebabkan karena kandungan air dan lemak sangat sedikit pada tulang normal sehingga tidak ada lemak yang tersuppress, menyebabkan gambaran cortex pada STIR terlihat lebih tegas.

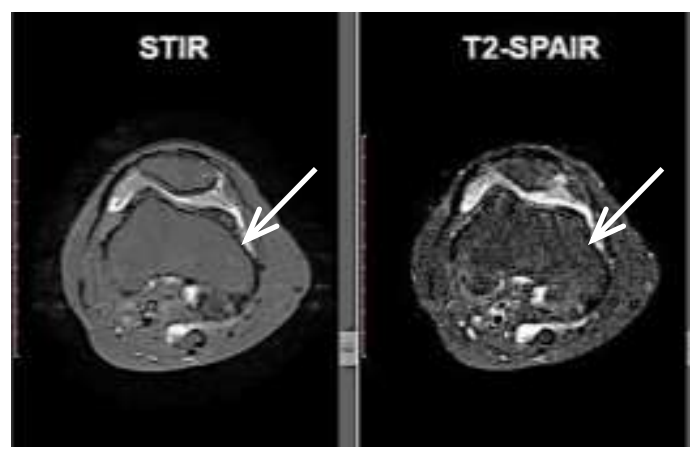

Gambar 2. Perbedaan citra pemeriksaan MRI Genu potongan aksial antara STIR dan T2-SPAIR untuk gambaran cortex (tanda panah).

Pada articular cartilage diperoleh hasil dari tabulasi silang bahwa $33 \%$ responden berpendapat sinyal lesi patologis pada articular cartilage pada T2-SPAIR terlihat cukup intens dibandingkan pada STIR. Validator (Ahli radiologi) menyatakan bahwa pada potongan aksial fat-sup hanya dapat menilai karakteristik sinyal dari articular cartilage. Sedangkan detail anatomis, ketebalan dan permukaan kartilago ini terlihat jelas pada potongan koronal T1W atau PDW dan sagital T1W atau PDW. Tanda panah pada gambar 4 menunjukkan sinyal lesi patologis pada articular cartilage pada sekuen T2-SPAIR terlihat cukup intens dibandingkan pada sekuen STIR.

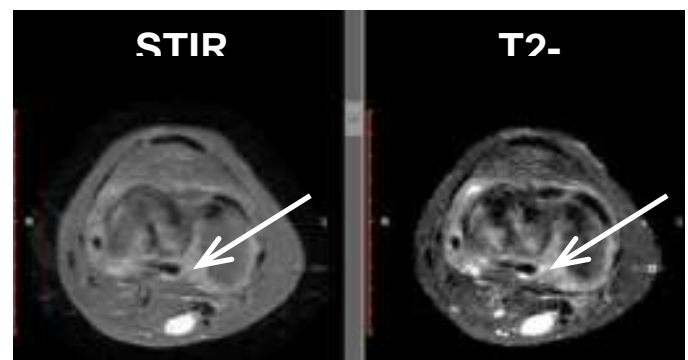

Gambar 3. Perbedaan citra pemeriksaan MRI Genu potongan aksial antara STIR dan T2-SPAIR untuk gambaran articular cartilage (tanda panah)

Pada ruang sendi diperoleh hasil dari tabulasi silang bahwa $50 \%$ responden berpendapat cairan sendi pada ruang sendi pada T2-SPAIR terlihat lebih intens (tampak lebih terang) atau lebih enhance dibandingkan pada STIR. Keunggulan potongan aksial genu dinyatakan oleh Liney (2006) bahwa selain tepat untuk menilai vaskularisasi, pemeriksaan MRI Genu khususnya potongan aksial sangat baik untuk menilai femoropatellar joint (ruang sendi).

Pada partial ACL dan PCL diperoleh hasil dari tabulasi silang bahwa $43 \%$ responden berpendapat sinyal lesi patologis pada partial ACL dan PCL pada T2-SPAIR terlihat lebih intens dibandingkan pada STIR. Validator (ahli radiologi) menyatakan bahwa pada potongan aksial fat-sup hanya dapat menilai intensitas sinyal dari gambaran partial ACL dan PCL. Sedangkan detail anatomis, posisi dan luas ACL dan PCL ini terlihat jelas pada potongan sagital oblik T1W dan PDW. Pada citra ini mendukung adannya gambaran ruptur ACL. Tanda panah pada gambar 6 menunjukkan sinyal lesi patologis pada partial ACL dan PCL pada T2-SPAIR terlihat lebih intens dibandingkan pada STIR.
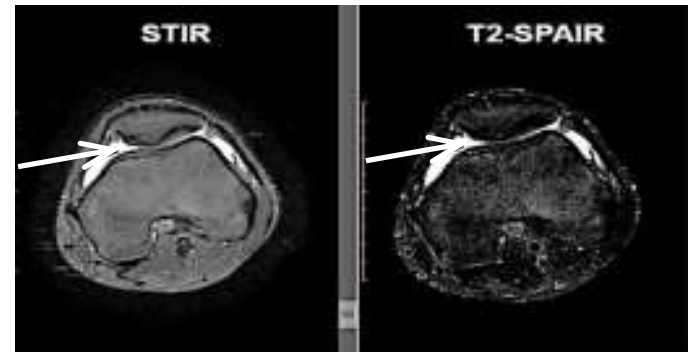

Gambar 4. Perbedaan citra pemeriksaan MRI Genu potongan aksial antara STIR dan T2-SPAIR untuk gambaran ruang sendi (tanda panah).

Pada soft tissue diperoleh hasil dari tabulasi silang bahwa $35 \%$ responden berpendapat sinyal lesi patologis bada soft tissue pada sekuen T2-SPAIR terlihat lebih intens dibandingkan pada STIR.

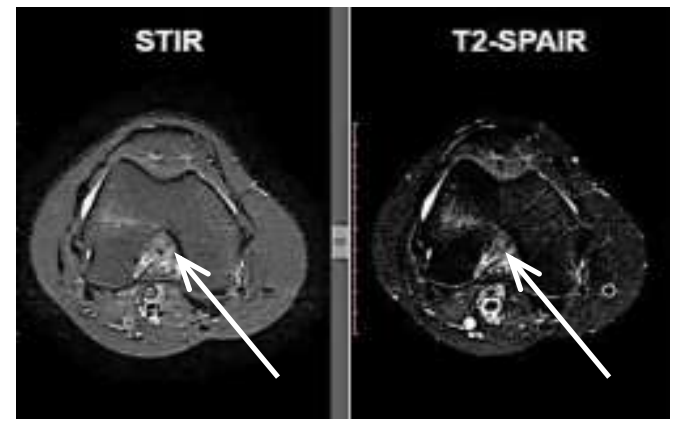

Gambar 5. Perbedaan citra pemeriksaan MRI Genu potongan aksial antara STIR dan T2-SPAIR untuk gambaran partial ACL dan PCL (tanda panah)

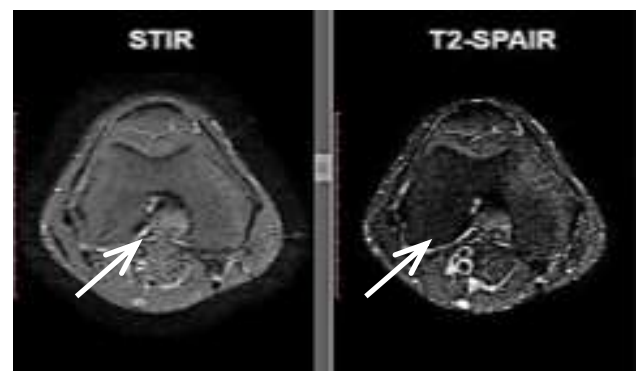

Gambar 6. Perbedaan citra pemeriksaan MRI Genu potongan aksial antara STIR dan T2-SPAIR untuk gambaran soft tissue (tanda panah).

Pada pembuluh darah diperoleh hasil dari tabulasi silang bahwa $50 \%$ responden berpendapat gambaran pembuluh darah pada T2-SPAIR terlihat lebih intens dibandingkan pada STIR. Menurut Westbrook (2008) pemeriksaan MRI Genu khususnya potongan aksial sangat baik untuk menilai vaskularisasi (pembuluh darah) dan juga sebagai tambahan 
informasi adanya kelainan patologis jika pada potongan sagital dan koronal belum bisa menegakkan diagnosa.

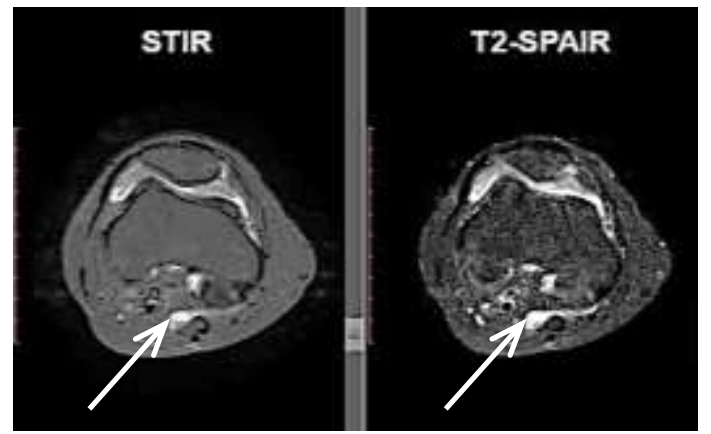

Gambar 7. Perbedaan citra pemeriksaan MRI Genu potongan aksial antara STIR dan T2-SPAIR untuk gambaran pembuluh darah (tanda panah).

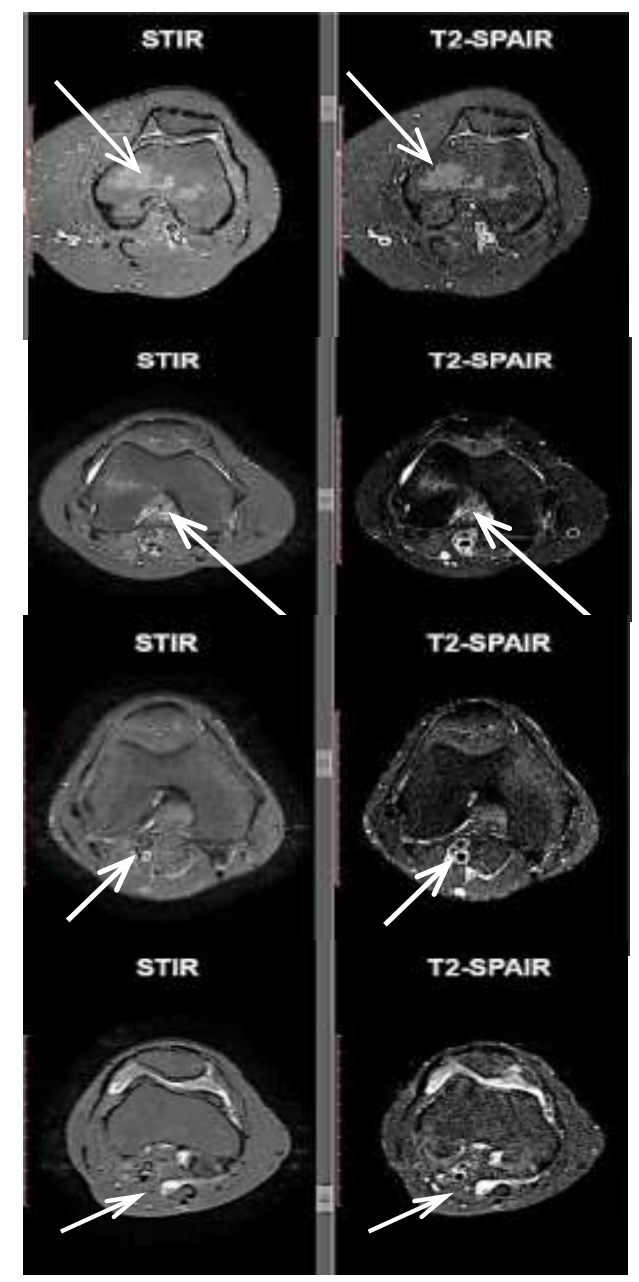

Gambar 8. Perbedaan citra pemeriksaan MRI Genu potongan aksial antara STIR dan T2-SPAIR untuk lesi patologis (tanda panah) pada empat pasien yang berbeda

Pada gambaran lesi patologis diperoleh hasil dari tabulasi silang bahwa $50 \%$ responden berpendapat sinyal lesi patologis pada T2-SPAIR terlihat lebih intens dibandingkan pada STIR.
Hal ini senada dengan penyataan Gonçalves (2011) bahwa teknik fat-sup dapat dimanfaatkan untuk deteksi oedem serta enhancement. Menurut Westbrook (2011) hal ini sering disebut dengan pembobotan patologis (Pathology-Weighting) apabila terdapat proses patologis (proses lesi atau oedem) maka kelainannya akan tampak terang pada gambar. Ribeiro (2013) juga menyatakan bahwa teknik fat-sup SPAIR merupakan salah satu teknik yang kuat untuk menekan lemak, yang memiliki berbagai keuntungan lebih dari teknik fat-sup konvensional.

Pada sebagian gambar menunjukkan bahwa lesi patologis, oedem, cairan sendi yang berlebih, pelebaran dan penyempitan pada pembuluh darah akan terdiferensiasi lebih baik pada sekuen T2-SPAIR.

Penulis setuju dengan pernyataan tersebut pada gambar 2 (tanda panah) menunjukkan bahwa lesi patologis pada T2SPAIR terlihat lebih intens daripada STIR. Pada gambar 5 (tanda panah) menunjukkan bahwa cairan sendi yang berlebih pada T2-SPAIR juga terlihat lebih intens daripada STIR. Pada dasarnya $\mathrm{T} 2 \mathrm{~W}$ menghasilkan gambaran cairan terlihat terang. Jika ada sumbatan, pelebaran maupun penyempitan pembuluh darah akan terlihat sangat informatif (gambar 8).

Salah satu keterbatasan dari penelitian adalah ini tidak terdapat pasien dengan curiga adanya suatu massa tumor atau abses. Apabila ada massa tumor atau abses, lemak dan cairan tentunya akan terdiferensiasi dengan baik pada sekuen T2SPAIR.

Teknik fat supression yang menghasilkan informasi citra lebih baik pada pemeriksaan mri genu potongan aksialerdasarkan penilaian secara umum yaitu dengan membedakan nilai total koresponden antara teknik fat-sup sekuen STIR dan T2-SPAIR, uji beda Wilcoxon Sign Test menunjukkan adanya perbedaan informasi citra yang bermakna antara teknik fat-sup sekuen STIR dan T2-SPAIR dengan nilai $p$ value $<0.001$. Pada gambaran bone marrow, articular cartilage, ruang sendi, partial ACL dan PCL, soft tissue, pembuluh darah dan lesi patologis secara umum didapat informasi citra T2-SPAIR lebih baik dibandingkan dengan STIR. Hanya pada gambaran cortex saja informasi citra STIR lebih baik dibandingkan T2-SPAIR. Diperoleh hasil bahwa nilai rangking rata-rata sekuen T2-SPAIR 15.5 dengan mean 2.73 lebih tinggi dibandingkan dengan rangking rata-rata sekuen STIR 0.00 dengan mean 1.00. Jadi secara umum menurut responden didapatkan citra T2-SPAIR merupakan teknik fat suppresion yang menghasilkan informasi citra lebih baik pada pemeriksaan MRI genu potongan aksial pada penelitian ini.

Hal ini senada dengan pernyataan Ribeiro (2013) bahwa teknik fat-sup SPAIR merupakan salah satu teknik yang kuat untuk menekan lemak, yang memiliki berbagai keuntungan lebih dari teknik fat-sup konvensional. Teknik ini ditandai dengan sifat sensitivitas rendah terhadap inhomogenitas pulsa $\mathrm{RF}$, dan hanya spin lemak yang ditekan. SPAIR menggunakan pulsa inversi pada adiabatic pulse yang selektif untuk mengembalikan spin lemak dalam volume yang dianalisis. Setelah pemberian pulsa adiabatik, spoiler besar digunakan untuk meniadakan sisa magnetisasi transversal. Spin lemak 
akan mengalami decay sesuai dengan laju relaksasi T1, dan setelah waktu karakteristik tertentu (TI null) magnetisasi longitudinal akan menjadi nol. Pada titik ini, pulsa eksitasi diterapkan. Saat spin lemak tidak memiliki magnetisasi longitudinal, lemak tidak akan memberikan kontribusi pada sinyal MR untuk ditampilkan dalam citra. Penerapan SPAIR sebagai teknik penekanan lemak akan mengakibatkan kejenuhan lemak yang lebih homogen dibandingkan dengan teknik penekanan lemak lainnya.

Menurut Mc.Robbie (2006) STIR bekerja dengan baik pada FOV lebar dan menurut (Phillips, 2011) SPAIR tepat dikombinasikan dengan sekuen $\mathrm{T} 2 \mathrm{~W}$ dan PDW, bekerja dengan baik pada FOV $<300 \mathrm{~mm}$. Pada penelitian ini FOV yang digunakan sebesar $160 \mathrm{~mm}$ jadi terbukti T2-SPAIR menghasilkan informasi citra lebih baik pada pemeriksaan MRI genu potongan aksial ini.

Melihat dari lamanya waktu scanning (scan time) antara STIR dan T2-SPAIR dapat dijadikan rujukan pemilihan sekuen tercepat. Scan time pengambilan sekuen STIR adalah 5:20. Sedangkan pada T2-SPAIR adalah 3:39. STIR membutuhkan waktu untuk inversion (mengembalikan sinyal), sehingga menjadikan scan time STIR lebih lama dibandingkan T2-SPAIR yang tidak membutuhkan waktu inversion. Apabila sekuen T2-SPAIR saja yang menjadi pilihan teknik fat-sup pada pemeriksaan MRI genu potongan aksial ini dapat menghemat waktu pemeriksaan selama 5 menit 20 detik. Hal ini sangat bermanfaat terutama dapat menghemat waktu tunggu pelayanan bagi pasien berikutnya.

Teknik fat-sup STIR hanya unggul dalam menggambarkan cortex. Sedangkan keterbatasan dari STIR antara lain waktu scanning lebih lama, suppresi lemak yang dihasilkan lebih lemah, lesi patologis pada hampir semua kriteria penilaian terlihat kurang intens kecuali pada cortex.

Teknik fat-sup T2-SPAIR unggul dalam hal antara lain waktu scanning lebih cepat, supressi lemak yang dihasilkan lebih bagus karena FOV pada penelitian ini $<300 \mathrm{~mm}$, penampakkan lesi pada bone marrow, articular cartilage, dan soft tissue sedikit lebih intens, penampakkan lesi pada ruang sendi terlihat lebih intens, jika ada cairan yang berlebih dapat terdiferensiasi dengan baik, penampakkan lesi pada ACL dan PCL (partially) terlihat lebih intens, jika terdapat ruptur dapat dilihat sebagian pada beberapa irisan aksial karena ACL dan PCL akan tampak jelas pada potongan sagital oblik, penampakkan pembuluh darah terlihat lebih intens, karena menggunakan T2 yang membuat gambaran cairan terlihat terang. Jika pelebaran maupun penyempitan serta sumbatan pada pembuluh darah akan terlihat sangat jelas, secara keseluruhan lesi patologis terlihat lebih intens dan sangat informatif dalam rangka membantu untuk mengakkan diagnosa karena potongan aksial ini sebagai tambahan informasi dari potongan koronal dan sagital. Sedangkan keterbatasan dari T2-SPAIR adalah terbatas dalam menggambarkan cortex dibandingkan dengan sekuen STIR. Cortex ini akan sangat baik terlihat pada sekuen T1W atau PDW.

Berdasarkan hasil penelitian ini penulis menyimpulkan bahwa tenik fat-suppressed yang digunakan pada pemeriksaan
MRI Genu jika FOV < $300 \mathrm{~mm}$ adalah sekuen T2-SPAIR. Sekuen T2-SPAIR sebagai citra pathology weighting akan menghasilkan informasi citra yang optimal dalam menegakkan diagnosa terutama dalam menampilkan lesi patologi. Selain itu, dilihat dari parameter scan time, T2SPAIR lebih cepat dibandingkan dengan sekuen STIR hal ini dapat mempercepat jalannya pelayanan pemeriksaan.

\section{SIMPULAN}

Berdasarkan uji beda Wilcoxon Sign Test menunjukkan adanya perbedaan informasi citra yang bermakna antara teknik fat-sup sekuen STIR dan T2-SPAIR dengan nilai $p$ value < 0.001. Hal ini menunjukkan bahwa Ho ditolak dan $\mathrm{Ha}$ diterima.

Berdasarkan uji statistik diperoleh hasil nilai mean rank sekuen T2-SPAIR 15.5 dan mean 2.73 lebih tinggi dibandingkan dengan mean rank sekuen STIR 0.00 dan mean 1.00. Jadi didapatkan hasil bahwa T2-SPAIR merupakan teknik fat suppresion yang menghasilkan informasi citra lebih baik dan waktu pemeriksaan lebih singkat dibanding STIR pada pemeriksaan MRI Genu potongan aksial.

\section{DAFTAR PUSTAKA}

Chhajer, Bimal. 2006. Knee Pain. Fusion Books : New Delhi, India

Elster, Allen D., 2016. Spectral Attenuated Inversion Recovery. www.mriq.com. Diakses 7 Februari 2016

Gonçalves, S.I. 2011. Methods for Fat Suppression. University Hospital Coimbra

Kartawiguna, Daniel. 2015. Tomografi Resonansi Magnetik Inti, Graha Ilmu : Yogyakarta

Liney, Gary. 2006. MRI in Clinical Practice. Springer Verlag, London, UK.

McRobbie. 2006. MRI From Picture to Proton, Second Edition. Cambridge University press : New York

Moeller and Reif. 2007,Atlas of Sectional Anatomy, Computed Tomography and Magnetic Resonance Imaging, Thieme : Stuttgart, New York.

Moeller and Reif. 2003, MRI Parameter and Positioning, Thieme : Stuttgart, New York.

Neseth, Roland. 2000. Procedures and Documentation for CT and MRI, McGraw-Hill Companies : USA

Riberio, Margarida et al. 2013. STIR, SPIR and SPAIR Techniques in Magnetic Resonance of the Breast : A Comparative Study, www.scirp.org/journal/jbise/. Diakses tanggal 1 Maret 2016.

Westbrook, Chaterine. 2008. Handbooks of MRI Technique, Third Edition. Blackwell Publishing : UK.

Westbrook, Chaterine and Kaut, Carolyne. 2011. MRI in Practice, Fourth Edition. Blackwell Publishing : UK. 